\title{
IMPACT OF COVID-19 LOCKDOWN IN TELECOMMUNICATIONS ENGINEERING COMPETENCY-BASED ALUMNI RANKING
}

\author{
Roberto Llorente, Miguel A. Rodríguez, Carlos Hernández, Jorge Sastre, Alicia \\ Carrión, Javier Madrigal
}

Universitat Politècnica de València (SPAIN)

\begin{abstract}
Higher education, as other social and economic sectors in Spain, was disrupted on $15^{\text {th }}$ March 2020 following health emergency Laws enacted related to COVID-19. Non-presential lecturing was stablished country-wide until the end of the academic year 2019-20, as society was set in lockdown. In this context, it is necessary to evaluate the impact of the mandatory changes implemented in the education paradigm in order to assess the degree of acquisition of general and specific competencies altogether the acquisition of transversal competencies, as an important factor for the alumni career.

This paper reports a comprehensive study on the competencies degree of acquisition considering the lockdown scenario in Spain. The results from the last four academic years have been comparatively evaluated in the core subject 'Teoría de la Comunicación', lectured in the fourth semester of the Telecommunications Engineering Integrated Program (Bachelor and Master) in the Universitat Politècnica de València, Spain, comprising data from 745 alumni. The results indicate that the degree of acquisition of technical competencies in this scenario has been adequate, being marginally better compared to previous academic year, probably due to new lecturing materials prepared. Nevertheless, the acquisition of the transversal competency 'analysis and problem solving' exhibits degraded results, indicating inhomogeneous acquisition probably due to limitations in the group-based problem-solving practice. The results suggest that specific materials and remote lecturing strategies should be developed and implemented to guarantee adequate acquisition levels.
\end{abstract}

Keywords: Competency assessment, non-presential lecturing, COVID-19 lockdown.

\section{INTRODUCTION}

Bologna-based engineering curricula in the European Higher Education Area (EHEA) are based on the acquisition of general, specific (technical) and transversal competencies [1]. Traditionally, general and specific competencies are acquired by presential lecturing and laboratory work. In the presential learning paradigm, transversal competencies are naturally acquired when performing professional-oriented activities implemented in different subjects along the alumni progression. The lecturing paradigm was modified on 15th March 2020, following health emergency Laws enacted in Spain [2]. In particular, the Universitat Politècnica de València (UPV), switched to a non-presential remote lecturing and examination paradigm until the end of the academic year 2019-20.

The switch to non-presential lecturing has been successful in general. Synchronous lecturing was swiftly implemented completing almost all scheduled timetables. In some cases, asynchronous lecturing materials were quickly prepared providing resources to alumni in order to fulfil the curricula subjects. These were not substantially altered, as reflected in the lecturing guides, 'Guía Docente', amendments supervised by the UPV and published to alumni and general public.

Following the change in the lecturing paradigm and after the completion of the final term of the academic year 2019-20, it is of great importance to evaluate the impact in of new lecturing paradigm in the level of acquisition of general and specific competencies, which are translated to the alumni ranking, and also the impact in transversal competencies acquisition. Trend evolution and correlation analysis in the subject 'Teoría de la Comunicación' have been performed considering data from the academic year 2015-2016 until academic year 2019-20 comprising a total of 745 alumni. The context of the analysis, the adequateness of the core subject selected for analysis, and the methodology employed are presented in the next section (Section 2). The analysis results and suggestions of adequate strategies are reported in Section 3. 


\section{METHODOLOGY}

The comparative study herein presented targets to evaluates the degree of acquisition of general and specific competencies altogether transversal competencies. Data from the last four academic years (from 2016-17 to 2019-20) have been evaluated in the core subject, 'Teoría de la Comunicación', taught in the fourth semester of the Telecommunication Engineering integrated program (bachelor and master levels) 'Ingeniero de Telecomunicación' [3]. The subject is studied by a large number of alumni each year (registration figures are: 189 students in the course 2016-17, 151 students in the course 2017-18, 188 students in the course 2018-19, 217 students in the course 2019-20) and the subject is an stablished control point to evaluate the transversal competencies Application and practical thinking (CT2) and Analysis and problem solving (CT3). It should be also noted also this subject is last core subject before alumni are divided in four study branches, thus the subject permits a coherent study covering the global alumni in a given academic year.

This subject requires 6 ECTS credits comprising 4.5 ECTS credits of classroom lecturing, 0.3 ECTS credits of classroom problem-solving work, and 1.2 ECTS credits of laboratory experimental practice, being part of the Signal Theory and Communications knowledge module. The subject covers key technical competencies for the telecommunications engineer, and it is also the last subject addressing signal-transmission specific competencies for some students, including those enrolled in a double degree program covering Telecommunications Engineering and Enterprise Management. In this context, the subject is designed to establish a solid conceptual base altogether advanced problemsolving capabilities and expertise in experimental work in the laboratory.

The technical contents of 'Teoría de la Comunicación' cover two main blocks:

1 The underlying theory of analog and digital communications

2 The basic aspects of signal detection and the corresponding transmission quality parameters

The subject describes the waveforms used in telecommunications, introducing the concept of modulation, both in time and frequency domain, as a convenient method to transmit analog waveforms or digital data through a linear and invariant channel [4]. Specifically, analog transmission (linear and angular modulations) and digital transmission techniques (both baseband and digital modulations), altogether optimum detection schemes maximizing key quality parameters as signal-to-noise ratio (SNR), the $\gamma$ parameter, and bit-error-rate (BER) in presence of additive white Gaussian noise are studied employing problem-based learning techniques [5].

\subsection{Competency-based ranking}

\subsubsection{Specific and General competencies}

The subject 'Teoría de la Comunicación' targets to provide the student the scientific foundation necessary to analyse the advantages and theoretical limitations of the main elements of a generic communications system employing analog or digital technology. This objective is achieved by the successful acquisition of general and specific competencies following Bloom's Taxonomy [6]. These general and specific competencies are defined by the degree's curriculum [7], which is supervised at national level by the ANECA, Government agency assessing Higher Education quality in Spain [8], and covers the technical and scientific contents of the subject.

\subsubsection{Transversal competency CT2: Application and practical thinking}

While general and specific competencies are overseen by the ANECA in Spain, transversal competencies are defined by the UPV for all Bachelor and Master degrees offered [9]. Moreover, specific control points are established in the curriculum to check the level of acquisition of each transversal competency for a given degree. In particular, the subject 'Teoría de la Comunicación' has been stablished as control point for the Application and practical thinking (CT2), and Analysis and problem solving (CT3) transversal competencies.

The transversal competency CT2, Application and practical thinking, is acquired by the student from the beginning of the University studies. The student, in the professional practice, needs to be prepared to face situations in which it is not enough to apply recipes or formulas, and in which the decisions or solutions that are proposed must be argued and are restricted by the available resources. In this way, the competency develops a way of thinking aiming to apply practical solutions adapted to new situations. In this way, this competency permits the student to: 
CT2: Apply knowledge to practice, taking into account the available information, and to establish a strategy to achieve the objectives effectively and efficiently.

The skills associated with the successful acquisition of this competency are:

- Apply to the professional practice the strategy and resources available to achieve objectives in common situations, based on previously known solutions.

- Design a coherent plan with concrete actions to tackle new situations.

Table 1 summarises the different acquisition levels for the learning outcome of CT2. The level descriptors (A, B, C, D) are established for the different indicators which reflect the capability of the student to apply to the professional practice the knowledge, skills and resources provided in the subject to successfully achieve technical objectives in common situations following instructions, as expected in the Level I ( $4^{\text {th }}$ Quarter) of the studies [9].

Table 1. Acquisition levels for transversal competency CT2: Application and practical thinking [9]

\begin{tabular}{|c|c|c|c|c|}
\hline \multirow{2}{*}{ INDICATORS } & \multicolumn{4}{|c|}{ LEVEL DESCRIPTOR } \\
\hline & D: Not achieved & C: In progress & B: Good/adequate & A: Excellent \\
\hline $\begin{array}{l}\text { Identifies the } \\
\text { objectives } \\
\text { following the } \\
\text { instructions }\end{array}$ & $\begin{array}{l}\text { Does not identify } \\
\text { the objectives }\end{array}$ & $\begin{array}{l}\text { Identifies some } \\
\text { objectives but does } \\
\text { not detect possible } \\
\text { obstacles for its } \\
\text { achievement }\end{array}$ & $\begin{array}{l}\text { Identifies all the } \\
\text { objectives and } \\
\text { detects some } \\
\text { obstacles to its } \\
\text { achievement }\end{array}$ & $\begin{array}{l}\text { Identifies both all the } \\
\text { objectives and the } \\
\text { obstacles following } \\
\text { instructions }\end{array}$ \\
\hline $\begin{array}{l}\text { Assesses the } \\
\text { quality of the } \\
\text { information } \\
\text { provided for its } \\
\text { application }\end{array}$ & $\begin{array}{c}\text { Does not } \\
\text { distinguish the } \\
\text { basic information } \\
\text { provided and/or } \\
\text { relevant }\end{array}$ & $\begin{array}{l}\text { Partially } \\
\text { discriminates the } \\
\text { basic information } \\
\text { from the irrelevant }\end{array}$ & $\begin{array}{l}\text { Discriminates all } \\
\text { relevant information } \\
\text { provided after } \\
\text { contrasting its utility }\end{array}$ & $\begin{array}{l}\text { Justifies the selection } \\
\text { of information } \\
\text { according to aspects } \\
\text { such as truthfulness, } \\
\text { appropriate to the } \\
\text { situation proposal, } \\
\text { updated, reliable, } \\
\text { accessible, etc. }\end{array}$ \\
\hline $\begin{array}{l}\text { Establishes the } \\
\text { process to } \\
\text { follow to get a } \\
\text { practical } \\
\text { solution from the } \\
\text { information, the } \\
\text { resources and } \\
\text { limitations }\end{array}$ & $\begin{array}{l}\text { Establishes a } \\
\text { process } \\
\text { incomplete and/or } \\
\text { inconsistent (no } \\
\text { considers all the } \\
\text { information, } \\
\text { resources and/or } \\
\text { limitations) } \\
\text { unsuitable to } \\
\text { reach a practical } \\
\text { solution }\end{array}$ & $\begin{array}{l}\text { Establishes a } \\
\text { process coherent } \\
\text { but incomplete } \\
\text { (does not consider } \\
\text { all the information, } \\
\text { the resources } \\
\text { and/or limitations) } \\
\text { suitable to reach a } \\
\text { practical solution }\end{array}$ & $\begin{array}{l}\text { Establishes a } \\
\text { process coherent } \\
\text { and complete } \\
\text { suitable to reach a } \\
\text { practical solution }\end{array}$ & $\begin{array}{l}\text { Establishes a } \\
\text { process well defined: } \\
\text { explains the steps } \\
\text { followed in the } \\
\text { process to obtain a } \\
\text { practical solution } \\
\text { (actions to be carried } \\
\text { out, necessary } \\
\text { resources and } \\
\text { temporal sequence) }\end{array}$ \\
\hline $\begin{array}{c}\text { Proposes } \\
\text { solutions and/or } \\
\text { concrete actions } \\
\text { after the analysis } \\
\text { of the situation }\end{array}$ & $\begin{array}{c}\text { Does not propose } \\
\text { solutions and/or } \\
\text { concrete actions } \\
\text { (lost in } \\
\text { digressions, } \\
\text { ambiguities, etc.) }\end{array}$ & $\begin{array}{l}\text { Suggests a solution } \\
\text { and/or concrete } \\
\text { action, although } \\
\text { erroneous (it is not } \\
\text { in line with the } \\
\text { objectives) }\end{array}$ & $\begin{array}{l}\text { Suggest a solution } \\
\text { and/or concrete } \\
\text { action appropriate to } \\
\text { the objectives }\end{array}$ & $\begin{array}{l}\text { Argues coherently } \\
\text { the solutions and/or } \\
\text { actions adopted }\end{array}$ \\
\hline
\end{tabular}

\subsubsection{Transversal competency CT3: Analysis and problem solving}

The transversal competency CT3, Analysis and problem solving, is also acquired from the beginning of the University studies as the student is facing engineering problems in different subjects. This competency is transversal to the contents of the subject and targets to give the capability to solve problems in new, non-expected situations that require a response employing novel techniques. Problem solving implies carrying out tasks that require more or less complex reasoning processes and, in many cases, not simply to apply a recipe. In this way, this transversal competency permits the student to:

CT3: The student must be able to apply structured procedures to solve problems, thus promoting the ability to learn, understand and apply knowledge autonomously. 
The skills associated with the successful acquisition of this competency are:

- To be able to carry out tasks that require more or less complex reasoning processes and, in many cases, not simply an associative or routine action.

- Identify and define the significant elements of a problem for its analysis and resolution in a correct and efficient way.

These skills are acquired in the context of a future career in telecommunication engineering, i.e. in the context of:

a) Solving basic analog communication problems.

b) Solving basic digital communication problems.

Table 2 summarises the different acquisition levels for the learning outcome of CT3. The level descriptors (A, B, C, D) are established for the different indicators which demonstrate that the student can analyse and solve a problem applying learned methods. This outcome is expected in the Level I (4th Quarter) of the studies [9]. More advanced levels (Levels II and III) require completely autonomous problem solving and the use of innovative techniques respectively.

\subsubsection{Evaluation and alumni ranking}

The evaluation of general and specific competencies has been performed in the new lecturing paradigm via open-response problems or multiple-response selection tests, without scheduling modifications, i.e. in the same dates and the same timing. After the switch to non-presential lecturing in the curse 201920 , all examination acts have been implemented by telematic methods employing an internal software tool, PoliformaT [10], with video supervision employing Microsoft Teams for the student identification.

The transversal competencies, due to their intrinsic nature, have been also kept in the same evaluation scheme, performed independently of the evaluation of general and specific competencies. Specifically, the evaluation and alumni ranking are carried out through the student's practical work, and through specific questions aimed at knowing the student's ability with respect to the evaluated competency. The student is always informed on which problems or questions are going to be used to perform an additional evaluation of the transversal competencies. It should be noted that the level of transversal competency acquisition is assessed in a completely independent way regarding final marks of the student for the general and specific competencies.

As shown in Table 1 and Table 2, each of the indicators established for the transversal competencies CT2 and CT3 is evaluated in the scale from A to D indicating a level of development not achieved (D), in progress (C), good/adequate (B) or excellent (A). This scale is internally established by the UPV for the measurement of transversal competency acquisition levels [9].

Specifically, the assessment of the degree of acquisition of the CT2 competency is carried out by:

- Assessment of the work delivered (tasks in PoliformaT) corresponding to the experimental work in the laboratory practice. For each student, the numerical simulation code (MATLAB software tool) generated is evaluated. In particular, the correct application to the different aspects of signal processing, modulations, etc. is checked.

- Specific question(s) in a laboratory practice test. Specific multiple-choice questions are presented to the student, such as what would be the most appropriate modulation or detection scheme in a certain environment explored in the laboratory.

Regarding the degree of acquisition of the transversal competency CT3, it is assessed by:

- The correct and complete resolution of a problem, including data gathering, parameters calculations, applying equations, drawing conclusions about the design of a system. The quality of the process presented is evaluated in this case. 
Table 2. Acquisition levels for transversal competency CT3: Analysis and problem solving [9]

\begin{tabular}{|c|c|c|c|c|}
\hline \multirow{2}{*}{ INDICATORS } & \multicolumn{4}{|c|}{ LEVEL DESCRIPTOR } \\
\hline & D: Not achieved & C: In progress & B: Good/adequate & A: Excellent \\
\hline $\begin{array}{l}\text { Defines the } \\
\text { problem } \\
\text { describing the } \\
\text { most important } \\
\text { aspects clearly } \\
\text { and concisely }\end{array}$ & $\begin{array}{l}\text { Does not } \\
\text { distinguish a } \\
\text { problem from a } \\
\text { list of data and } \\
\text { instructions }\end{array}$ & $\begin{array}{l}\text { Distinguish a } \\
\text { problem from a list } \\
\text { of data and } \\
\text { instructions with } \\
\text { help from an } \\
\text { expert }\end{array}$ & $\begin{array}{l}\text { Define the } \\
\text { problem } \\
\text { identifying the } \\
\text { most relevant } \\
\text { data } \\
\text { autonomously }\end{array}$ & $\begin{array}{c}\text { Accurately defines the } \\
\text { problem, identifying } \\
\text { the causes, its data } \\
\text { and unknowns }\end{array}$ \\
\hline $\begin{array}{l}\text { Uses the } \\
\text { indicated } \\
\text { information } \\
\text { sources and } \\
\text { selects the } \\
\text { correct data }\end{array}$ & $\begin{array}{c}\text { Collects } \\
\text { information, but } \\
\text { is irrelevant } \\
\text { and/or } \\
\text { insufficient }\end{array}$ & $\begin{array}{l}\text { Collects } \\
\text { information } \\
\text { relevant in a way } \\
\text { incomplete and } \\
\text { disjointed }\end{array}$ & $\begin{array}{l}\text { Collects relevant } \\
\text { and sufficient } \\
\text { information to } \\
\text { solve the problem }\end{array}$ & $\begin{array}{l}\text { Collects necessary } \\
\text { information to solve } \\
\text { the problem and } \\
\text { justifies its utility }\end{array}$ \\
\hline $\begin{array}{l}\text { Uses a learned } \\
\text { method for the } \\
\text { resolution of the } \\
\text { proposed } \\
\text { problem }\end{array}$ & $\begin{array}{l}\text { Does not } \\
\text { employ a } \\
\text { learned method } \\
\text { to solve the } \\
\text { proposed } \\
\text { problem }\end{array}$ & $\begin{array}{l}\text { Uses a learned } \\
\text { method to solve } \\
\text { the proposed } \\
\text { problem and } \\
\text { outlines the } \\
\text { resolution process }\end{array}$ & $\begin{array}{l}\text { Uses a learned } \\
\text { method to solve } \\
\text { the problem, } \\
\text { outlines the } \\
\text { resolution } \\
\text { process and } \\
\text { justifies the } \\
\text { calculations in } \\
\text { each stage (data, } \\
\text { equations, etc.) }\end{array}$ & $\begin{array}{l}\text { Uses a learned } \\
\text { method to solve the } \\
\text { problem, outlines the } \\
\text { resolution process, } \\
\text { justifies the } \\
\text { calculations in each } \\
\text { stage (data, } \\
\text { equations, etc.), and } \\
\text { values its adaptation } \\
\text { (limitations, } \\
\text { hypothesis, etc.) }\end{array}$ \\
\hline $\begin{array}{l}\text { Analyzes } \\
\text { consistency of } \\
\text { the obtained } \\
\text { solution(s) }\end{array}$ & $\begin{array}{l}\text { Does not } \\
\text { identify whether } \\
\text { the result is } \\
\text { consistent }\end{array}$ & $\begin{array}{l}\text { Identifies whether } \\
\text { the result is } \\
\text { consistent }\end{array}$ & $\begin{array}{l}\text { Justifies the } \\
\text { consistency of the } \\
\text { result }\end{array}$ & $\begin{array}{c}\text { Critically analyzes the } \\
\text { coherence and } \\
\text { implications of the } \\
\text { obtained solution }\end{array}$ \\
\hline
\end{tabular}

\section{COMPETENCY ACQUISITION}

The data gathered from the course 2016-17 through 2019-20 permits to evaluate the alumni marks related to general and specific competencies, and also the transversal competencies acquisition levels. These are summarised in Figure 1 to Figure 3. In particular, Figure 1 shows the evolution of the general and specific competency marks. The marks for the academic year 2019-20 include the effect of the population lockdown, and the full switch to non-presential methods, including lecturing and examination. The results indicate that the level of acquisition is adequate and in line with the levels of the previous years. It should be noted that the year 2016-17 was the first year where new materials where prepared and the new examination methods were implemented. These materials and methods have been maintained for the whole academic series evaluation.

Table 3 shows the mean and standard deviation of the general and specific competencies marks presented in Figure 1. It can be observed that no specific degradation in the marks is observed in the academic year 2019-20, indicating that the measures taken to implement non-presential lecturing have been adequate and have mitigated the lockdown lecturing limitations. 


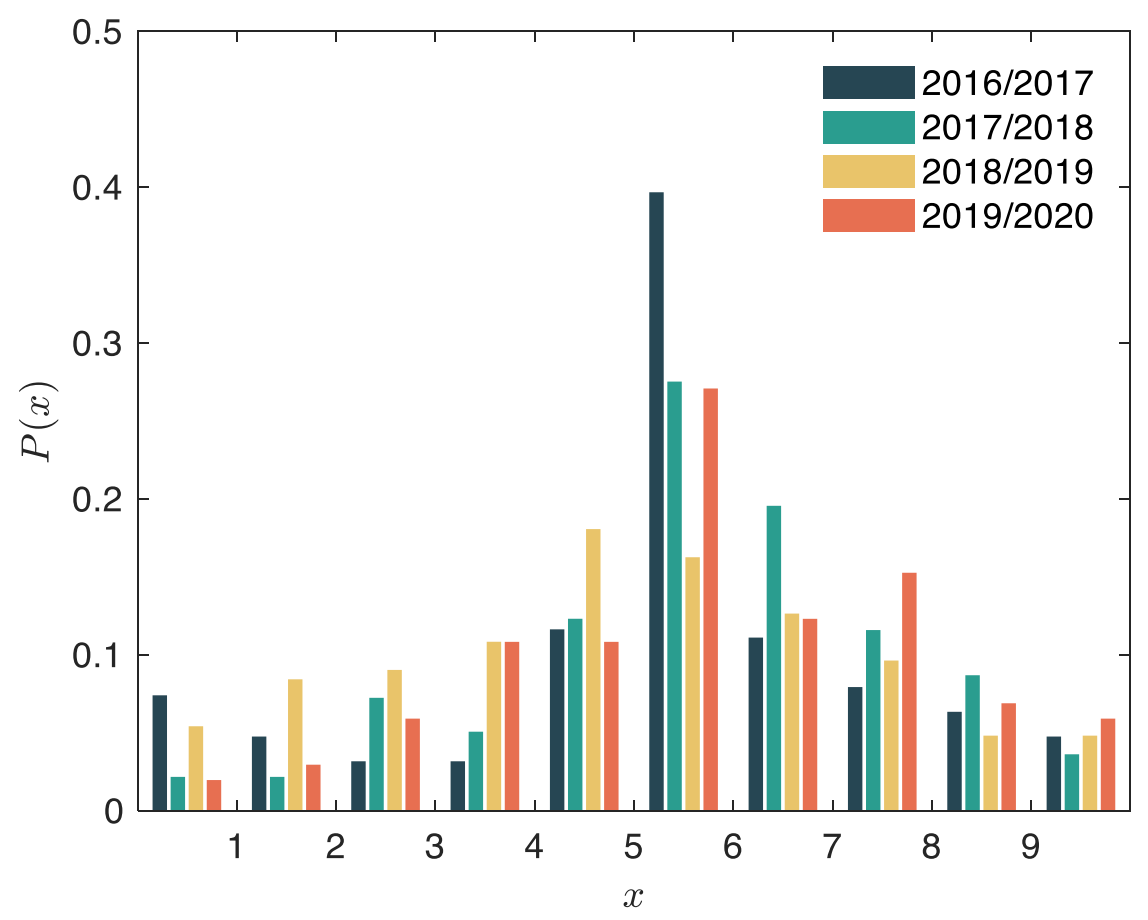

Figure 1. Probability density of the final marks for general and specific competencies (marks range from 0 to 10 Points). Evolution considering academic courses from 2016-17 to 2019-20.

Table 3. Mean $(\mu)$ and standard deviation $(\sigma)$ of the marks for general and specific competencies (marks range from 0 to 10 Points) for the academic courses from 2016-17 to 2019-20.

\begin{tabular}{|c|c|c|c|c|}
\cline { 2 - 5 } \multicolumn{1}{c|}{} & $2016 / 17$ & $2017 / 18$ & $2018 / 19$ & $2019 / 20$ \\
\hline$\mu$ & 5.20 & 5.69 & 4.88 & 5.51 \\
\hline$\sigma$ & 2.24 & 1.91 & 2.34 & 2.08 \\
\hline
\end{tabular}

Figure 2 and Figure 3 show the probability density for the transversal competencies CT2 and CT3 respectively. The results indicate that the level of acquisition of competency CT2, Application and practical thinking, has improved. This is probably due to the non-presential laboratory work. This work is done coding specific MATLAB software functions. In the lockdown scenario (course 2019-20) the students have unlimited time for the implementation of MATLAB code, which permits the extensive use of programming resources, which in turn improves the quality of the code generated.

The results shown in Figure 3 indicates that the level of acquisition of competency CT3: Analysis and problem solving has been degraded due to the lockdown scenario. Problem solving is exercised in the subject under analysis via group-based problem-solving examples, where the underlying theory is applied to different scenarios. Once a problem is presented to the students, an out-of- the-box thinking is encouraged to find an action course to solve the problem. The lecturer guides the process and discusses the solution to the problem, considering different action coursed (time domain or frequency domain, by example) where possible. The group-solving strategy is limited when non-presential lecturing via videoconference is employed. The variable quality of the students' connectivity, and limitations in the computing devices available are reflected in a limited discussion on the problem-solving cases, which difficult the student knowledge building required in this transversal competency. 


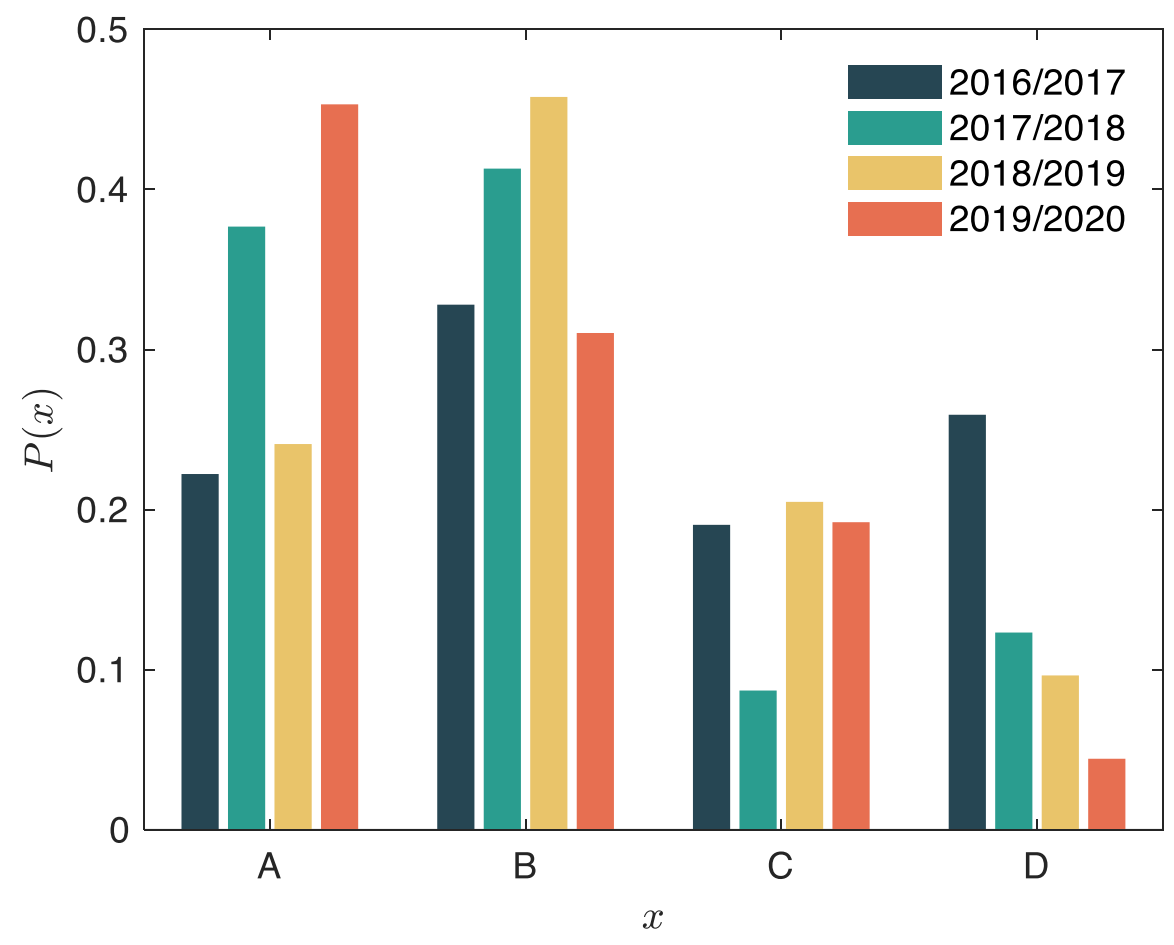

Figure 2. Probability of acquisition level (A, B, C or D) for the transversal competency CT2: Application and practical thinking. Evolution considering academic courses from 2016-17 to 2019-20.

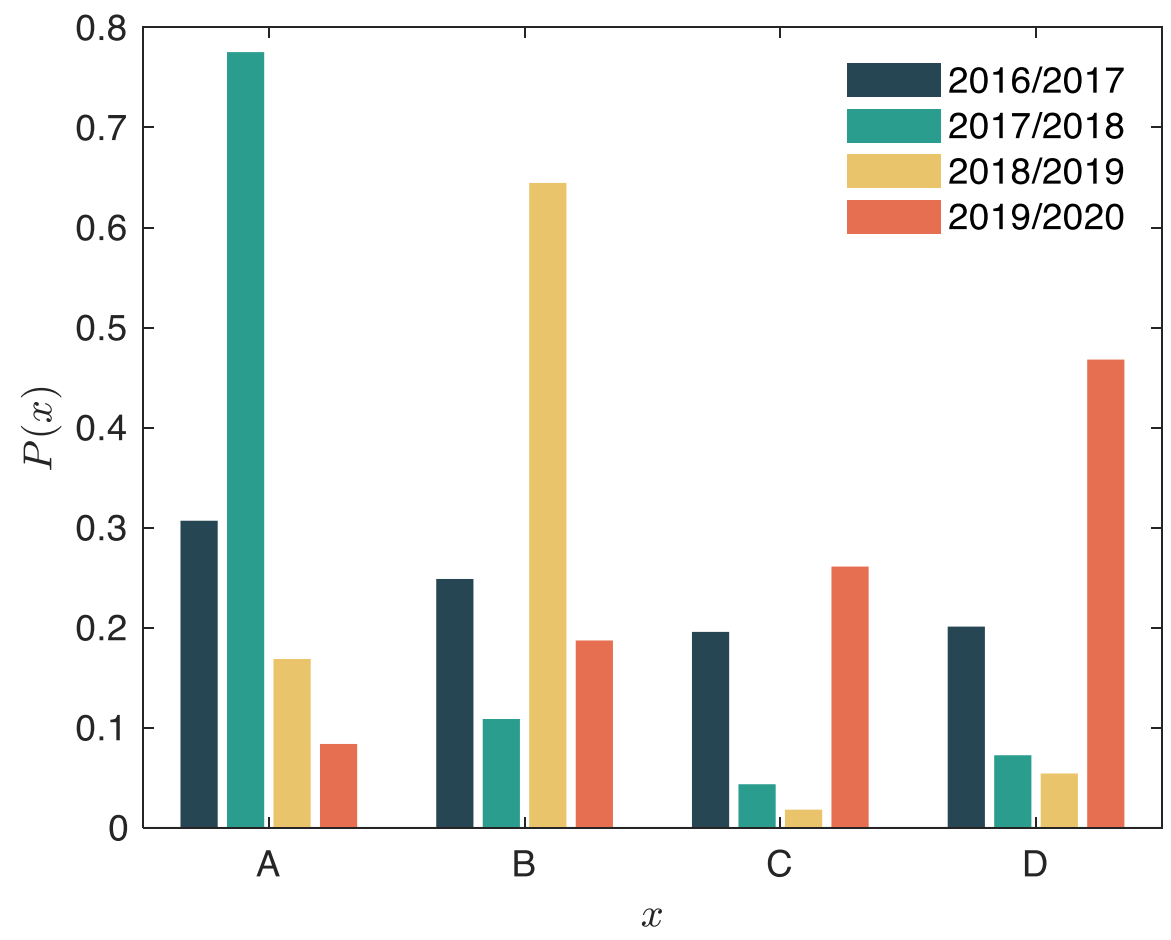

Figure 3. Probability of acquisition level (A, B, C or D) for the transversal competency CT3: Analysis and problem solving. Evolution considering academic courses from 2016-17 to 2019-20.

It is also interesting to evaluate the correlation between the general and specific competencies final marks, versus the transversal competencies acquisition levels. Figure 4 and Figure 5 show the $90 \%$ confidence intervals for the final marks ( 0 - 10 Points) corresponding to each acquisition level $(A, B, C$ or D) in competencies CT2 and CT3 respectively. The variance of the population is assumed to be 
unknown, and therefore, the Student's t-distribution is employed. The results indicate that no special degradation in the correspondence is observed in the academic year 2019-20.

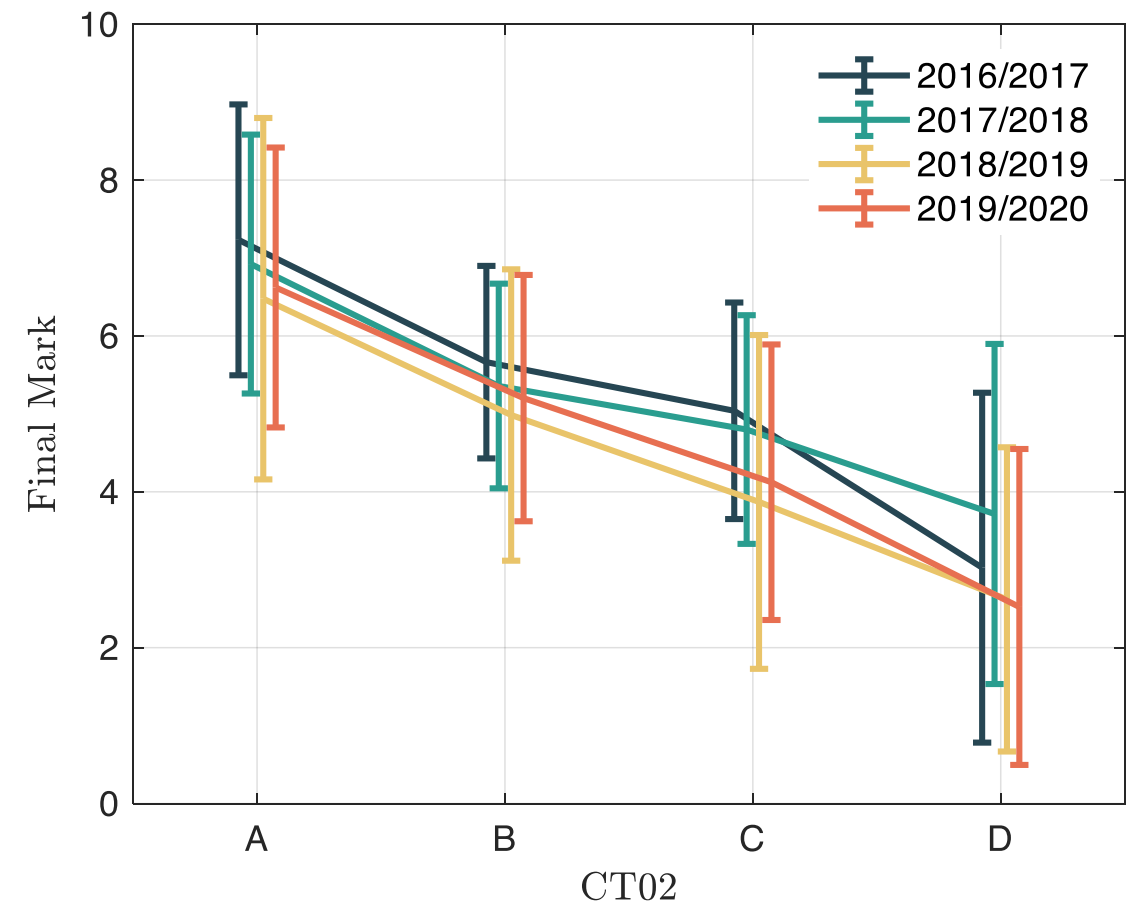

Figure 4. Correlation between marks ( $0-10$ Points) and CT2 acquisition levels (A, B, C or D). Intervals show 90\% confidence. Evolution considering academic courses from 2016-17 to 2019-20.

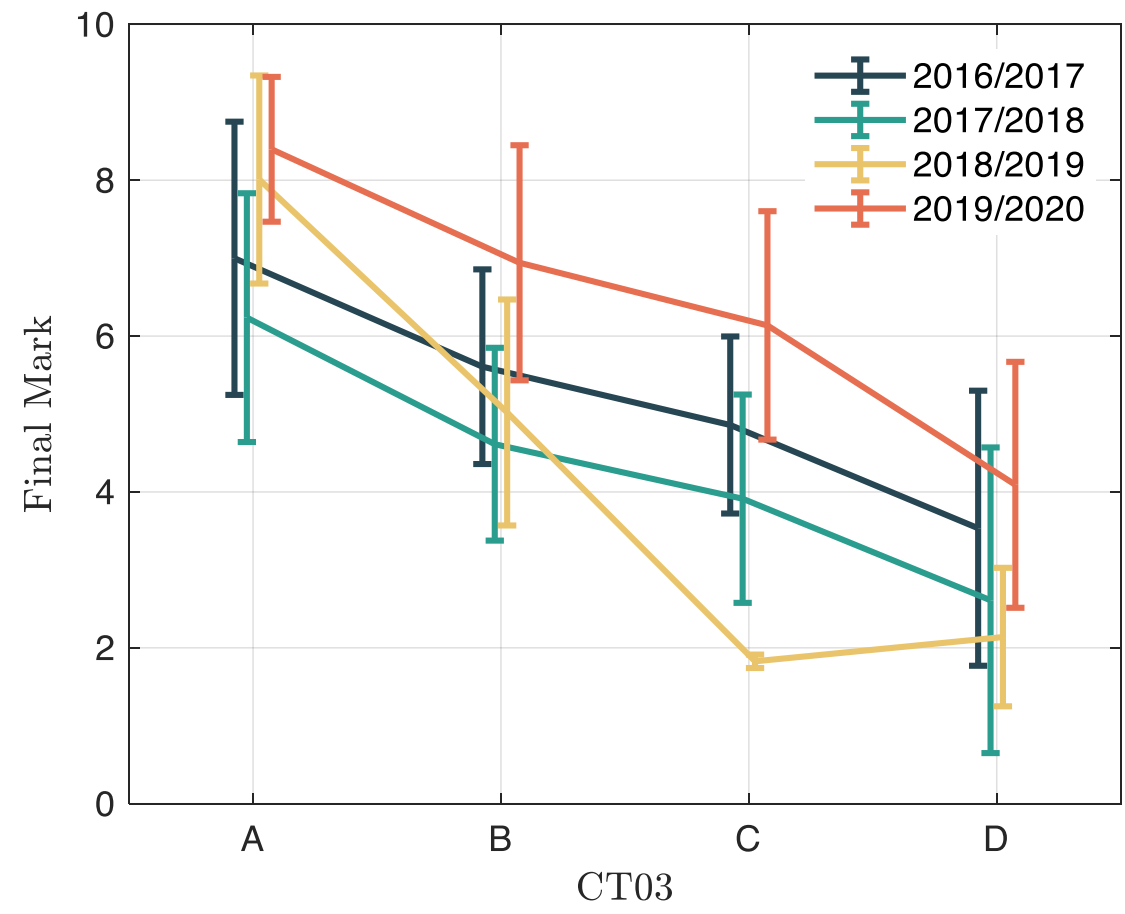

Figure 5. Correlation between marks ( $0-10$ Points) and CT2 acquisition levels (A, B, C or D). Intervals show 90\% confidence. Evolution considering academic courses from 2016-17 to 2019-20. 


\section{CONCLUSION}

The comparative results evaluated through historic data indicate that the degree of acquisition of general and specific competencies in the lockdown scenario is adequate, being marginally better compared to previous academic year, probably due to the adapted lecturing materials prepared to address the suspension of presential lecturing. Nevertheless, the acquisition of the CT3 transversal competency, Analysis and problem solving, which benefits from group-based activities, is degraded. This indicates inhomogeneous level acquisition. These results suggest that specific non-presential lecturing strategies employing videoconference and ad-hoc materials should be developed and implemented to guarantee adequate competency acquisition.

\section{ACKNOWLEDGEMENT}

The support by the 2020 Science Parks program from the Consellería de Innovación, Universidades, Ciencia y Sociedad Digital, Generalitat Valenciana, Spain, is acknowledged.

\section{REFERENCES}

[1] European Commission/EACEA/Eurydice. "The European Higher Education Area in 2015: Bologna Process Implementation Report," Publications Office of the European Union, Luxembourg, 2015.

[2] "Real Decreto 463/2020, de 14 de marzo, por el que se declara el estado de alarma para la gestión de la situación de crisis sanitaria ocasionada por el COVID-19," Diario oficial Boletín Oficial del Estado, 2020. Retrieved from URL: https://www.boe.es/diario_boe/txt.php?id=BOE-A-2020-3692.

[3] "Programa Integrado Ingeniero de Telecomunicación," Universitat Politècnica de València, 2020. Retrieved from URL: https://nitfoc3.etsit.upv.es/docencia/programa-integrado.html

[4] A. Bruce Carlson, "Communication systems," Tata McGraw-Hill Education, 2010.

[5] Diana F. Wood, "Problem based learning," BMJ, vol. 326.7384 (2003), pp. 328-330.

[6] B. S Bloom et al. "Taxonomy of educational objectives: The classification of educational goals. Handbook I: Cognitive domain", David McKay Company, New York, 1956.

[7] "Orden CIN/355/2009, de 9 de febrero, por la que se establecen los requisitos para la verificación de los títulos universitarios oficiales que habiliten para el ejercicio de la profesión de Ingeniero de Telecomunicación", Diario oficial Boletín Oficial del Estado, 2009. Retrieved from URL: https://www.boe.es/boe/dias/2009/02/20/pdfs/BOE-A-2009-2894.pdf

[8] "Bachelor's Degree and Master's Degree Regulations," Retrieved from URL: http://www.aneca.es/eng/Evaluation-Activities/Evaluacion-de-titulos/VERIFICA/Bachelor-sDegree-and-Master-s-Degree/Regulations

[9] "Proyecto Competencias Transversales UPV," Universitat Politècnica de València, Retrieved from URL: http://www.upv.es/entidades/ICE/info/Proyecto_Institucional_CT.pdf

[10] Hector Moreno Ramón et al. "Evaluación de Competencias Transversales en un entorno 3.0: Lessons (Sakai)," In-Red 2017, III Congreso Nacional de innovación educativa y de docencia en red, Editorial Universitat Politècnica de València, 2017. 